\title{
The global context of authoritarian populism as democratic pylon to Fascism, and a tutorial from the Balkans
}

\author{
Faruk Hadžić * A \\ A Independent researcher, Bosnia and Herzegovina
}

Received: December 07, 2020 | Revised: December 12, 2020 | Accepted: December 31, 2020

DOI: $10.33445 /$ sds.2020.10.6.7

\begin{abstract}
The paper focuses on the political position populism occupies in representative democracies as an inclusionary pylon for fascism, with the analog review of the Balkans and its global security lessons. Populism implies a constant conflict between elite, establishment, alienated structures linked to interests contrary to the public or members of other ethnoreligious backgrounds. Both left and right populism aim at a particular political and social homogeneity. The phenomenon of increased countries with developed democratic institutions and standards with authoritarianism leads to a closed circle of global "legitimate-democratic" violence, in which democratic institutions and standards, human and minority rights, and freedoms will be a danger. The Balkan's lessons in dealing with similar individuals and movements that promote the "cleansing" of Europe and preserving an "identity" artificially tailored to others' hatred are proactivity. The Balkans' (un)-successful fight against the historical forms of right-wing extremism in more current circumstances have become like an overflowing foundation of global right-wing networks. Humankind's great concern stems from the increasingly aggressive foreign policy, xenophobic sentiment, and the growing inclination of the autocratic populist government to stop the transition of violence to democracy in the scientifically-technologically and culturallyspiritually objectively connected global community. Solutions based on opportunism and manipulation do not offer anything concrete that could improve the socio-political-securityeconomic situation. When a liberal sees that certain elements use coercion to regulate social relations according to their desire, to force the whole of society on acceptable socio-economic behavior, the liberal should feel a personal responsibility to stand up for freedom.
\end{abstract}

Key words: populism, authoritarianism, violent democracy, global security, liberalism, Balkans.

\section{Introduction}

This paper starts from the point of view that the strength of populist parties and movements today, and the radicalization of the European political space in general, is a security threat and should be seen as a symptom of the crisis of global democracy, by elaborating on my formative assessment of the relationship between populism and violent democracy, and the analog review of the Balkans and its global lessons. The "democratic-electoral" strategy of authoritarian populism represents the greatest threat to democratic norms and practices. The rise of authoritarian populism, neo-nationalism in the Balkans, which is increasingly flattering and approaching autocratic/nationalist populist regimes and parties in the immediate vicinity and around the world, is brought to the fore as a consequence of the threat to national, cultural, and religious identity that comes with the refugee crisis, and migratory movements.

Populism is a rather complex phenomenon that appears in many forms and very different contexts. As such, it is difficult to grasp, and scholars who deal with it will often characterize

\footnotetext{
* Corresponding author: BSc Psychology, Economics, MSc Security studies, Criminal Justice and Law enforcement Studies, MBTA, Mindfulness-based Transactional Analysis, e-mail: faruk.hadzic01@gmail.com, ORCID: 0000-0003-1158-7858
} 
it as a phenomenon that "eludes" clear definition. Populism is a pervasive topic in the scientific literature in the European "West", parties, and movements. The term populism is mostly used in a derogatory sense, to denote political actors who act demagogically and tend to make unrealistic and false promises to gain support citizens. In political competition, therefore, the term is mostly used as a rhetorical tool against certain political actors, i.e., as an expression intended to discredit political opponents (Salaj and Grbeša, 2017, p. 322). Namely, right-wing populist parties managed to impose themselves as a significant political force in post-World War II Europe with a period of somewhat more intense strengthening in the 80 s and general power retention in the 90 s and 2000s (Mudde, 2013). Unlike the right, left populism starts from the assumption of a homogeneous society falling apart with the penetration of capitalism, both at home and across borders. The populist strategy of full "mass employment" shows all its internal fragility and unsustainability as soon as it encounters the operation of free-market law in which the strategy of "stable employment" is automatically replaced by a strategy of "price stability" leading to unemployment and real valorization of debt. Unemployment leads to productivity growth and profit growth, weakening labor unions weakened by restrictive legislation and unable to protect drastic employment and wage declines. In contrast, parliament increasingly protects banks' interests and the technocratic-political establishment that realistically control society's economy. Some populist parties present themselves as "real" representatives of the people, fighting against the "elites". Some authoritarian populists want a democracy that will not be limited and "slowed down" by the rule of law, so they often advocate more referendums and "direct" democracy. Some of these parties are in favor of more state involvement in society and the economy. For some, the state should take more responsibility, which is why some of these parties are against institutions that limit state power and sovereignty, such as the EU and NATO. Historically, fascism was made possible by the produced nation-state development imbalance's processes characteristically strengthened in the mature stage of civic liberalism. Through the national constitution, the civil contradictions of liberalism are manifested. In proportion to the inherent implications of civil disability in its mature stage, the dynamism of these contradictions remains organized and are expressed in the nation, that is, in this sense, authoritative state-negatively organized legitimacy. Infrastructurally provided, balanced civic dynamism structures, articulates, systematizes, or more consistently directs civil contradictions to authority state regulation.

Authoritarian gender means a gap towards political democracy, acceptance of hierarchy (including an undemocratic order based on the national leader's authority, for example), belief in a strong state that is the guarantor of solving political and economic problems, connection with national exclusivity. Liberalism is the opposite, accepting the principles of the liberal economic order of private property, markets, economic and political freedom, and nonacceptance of authoritarian and nationalist ideologies (Hadžić, 2020, p. 44).

At the global level, one of the influential themes of the crisis of democracy is that of Colin Crouch's post-democracy. The striking neologism "post-democracy" denotes a sociopolitical situation in which "while the framework of democracy remains fully in force (...) politics and power increasingly slide back into the hands of privileged elites in a manner typical of the pre-democratic period" (Crouch, 2007, p. 12). A feature of the current crisis of democracy (called the post-democratic state or any other name) is the simultaneous withdrawal of political parties from attempts to control the economy, especially financial markets, and interest in 
limiting citizen political participation to general elections only. Thus, the conditions were agreed for populism, mainly encouraged by mass unemployment, to accept the nationalist ideology and protectionist and interventionist measures, which enabled not only authoritarian rule but also the use of that power to homogenize the goals of the nation and mobilize society. This last step is not necessary and is probably not easy to do in the absence of an external companion.

Pluralism and social constructivism have opened up new perspectives in the study of security. The study of human security occupies an increasing space and more attention to the individual's security. Human security is a broad term consisting of two categories - "freedom from scarcity" and "freedom from fear". The first term represents a broader definition and includes threats such as famine, infection, repression, and protection from a sudden disaster. The second term emphasizes threats to the individual (e.g., drug trafficking, mines, ethnic conflicts, dysfunction of the state, tradein small arms). The "freedom from fear" approach focuses on the immediate necessity.

We can problematize that there has been a change in value orientations in the Balkans and globally by accepting or rejecting groups of attitudes relating to a particular sphere of social action. These are the economic and political organization of society, where different views, value dimensions of economic-political liberalism (rejection or acceptance of the basic principles of liberal society - private property, market, multi-party democracy). One of them is political authoritarianism, which we assume is the opposite of economic-political liberalism and is based on opposition to individual freedoms and statism, the glorification of the state's role. Then there is national exclusivism, which is based on the idea that nations should be separated, that members of different nations cannot live together (it is just one dimension of the much broader notion of nationalism). In a broader socio-political sense, nationalism became the main proponents of the ideology of exclusion, 'very quickly became allies in the exYugoslavia', (Papić, 2012), which further weakened and impoverished all others who did not support such discourses. Perhaps the best example of nationalist populism in ex-Yugoslav countries is the objection to alienated society's strata for civism or anti-chauvinism or both. These are small and underdeveloped exYugoslav countries. Therefore, these accusations are associated with anticolonialism and one or another type of intellectual corruption out of, sometimes alleged, feelings of inferiority, and much more often due to direct or covert corruption. All of them, usually unspecified, are opposed to the people's true interests or, put, to the people - real, authentic, right or orthodox, and patriotic. Probably the best example is the book Filozofija Palanke by R. Konstantinović. He analyzes in detail the fear of an open society, primarily on the example of Serbian poetry. On the other hand, critics advocate one or another type of closed society, if not directly, then indirectly, emphasizing the need for a permanent commitment to national and state interests in cultural policy, not to mention domestic and foreign policy.

In order for the populists to win power, it is necessary to change the public space. Democracy, in principle, allows for the individualization of interests because everyone has one vote, so these individual votes are collected in elections to gain enough support to take power. So, to encourage the pluralization of the political space and its division into majority and minority. Besides, neither individual nor collective consistency is necessary, at least not over time - democracy is a system in which the people and the authorities can change their minds (say every fourth year). The latter is important because it provides the necessary flexibility in conditions when circumstances change. In these circumstances, that is, in circumstances when democracies function properly, pluralism of interests and party competition based on it stabilize the government and strengthen its legitimacy, because it provides the necessary flexibility in 
conditions when circumstances change. What separates liberals from other political ideologies is that liberals are self-centered and are not interested in either society or the common good. A liberal should be the first to understand that his benefit depends mainly on cooperation with others, on the society in which he lives, on mutual human interactions, and not on the state's institutional coercion.

\section{Material and methods}

This paper starts from the point of view that the populist parties and movements' strength, within the radicalization of the political space, is a critical security paradigm and a symptom of the crisis of democracy throughout Europe and the world. An essential step is to elaborate on my formative assessment of populism and explain the relationship between populism and violent democracy. Employing analytic techniques of concept clarification, it descriptively specifies the stereotype of populist platforms as identified in extant research. It thereby focuses on the political position populism occupies in representative democracies as an inclusionary pylon for fascism, with the analog review of the Balkans and its global security lessons.

\section{Results and discussion}

The global context of authoritarian populism and fascism

When it comes to totalitarian regimes between the two world wars, they grew out of ideological and economic populism because they had war goals of one kind or another. A foreign enemy is needed to achieve the necessary homogenization and maintain totalitarian rule when it begins to lose the support and trust of the people. Populism can be both left and right and progressive and reactionary and occur in developed and developing countries (Arditi, 2005). Radical populism or populism in the narrow sense is an anti-elitist and anti-systemic thin-centered ideology that includes the division of society into "us" (just people) and "them" (opponents of a just people), bypassing the democratic process and destroying or weakening some political institutions. Radical populists (whether populist parties or movements) question, and most often reject, the model of representative democracy and associated democratic institutions. Instead of the pluralistic political model characteristic of liberal democracies, they construct a dualistic vision of the political system in which they try to portray themselves as "direct representatives of the people" and portray all other politicians as preventing the will of the "people" from being implemented, along with democratic institutions built.

Although it is a relatively new phenomenon on the European political scene, authoritarian populism attracts an increasing number of voters. Since the 1980s, authoritarian populism has been the fastest-growing ideology in Europe, and there is no indication that this will stop. The dominance of populist political parties is visible today in societies without a significant democratic background, as well as in countries with a long democratic tradition and a developed system of democratic institutions, where populist parties dominate or participate in parliamentary coalitions, increasingly controlling the legislature, judiciary, and executive. Two ideological blocs have long dominated European politics: conservative, i.e., Christian Democrat, and social-democratic. However, in 2017, authoritarian populism recorded $15 \%$ support, which is more than the support that liberal parties received (Timbro, 2017). The authoritarian populism has become the third most represented ideology in Europe, right behind the Christian Democrat right and the Social Democrats, while liberalism is in fourth place.

Mainstream populism can be defined as a political style or a way of political 
communication of mainstream (non-radical) political actors, a style that contains some elements inherent in radical populism, but the actors who use it retain a pluralistic vision of the political system as is the case with Berlusconi in Italy or Victor Orban in Hungary (Mudde, 2013). In Sweden, the Sverigedemocratic, right-wing populist party is the second strongest party, while the Five Star Movement in Italy is the party with the most support. We have a growth of populist options that draw their strength from pure, uncontrolled, undirected, and unconstructive rebellion. During the crisis, this became a problem in most European countries, from Greek and Spanish left-wing populists to right-wing populists in France, the United Kingdom, the Netherlands, and many other countries. Although the form of these "antiregime" movements was different, depending on the social problems that could be used as a basis for populism, the reason was the same: disillusionment with the political process and the political mainstream. Due to the wave of migrants in the current migrant crisis, the inferior social status of minorities, the strengthening of right-wing parties, the size of minority groups, growing economic insecurity of Western countries, and the growing fear of losing national identity in an environment of globalized culture, some countries perceived multiculturalism as a danger to national identities and balance in societies. (Hadžić, 2020, p. 23) It is also necessary to recall the controversial novel by French author Jean Raspail from 1973, "Camp of the Saints" in which he prophetically speaks of the mass immigration of people from third countries to France and Europe. In addition to intense racism and xenophobia, this novel has been marked for the past four decades as a kind of ideological pamphlet for political orientations towards migrants, mostly Muslims, Africans, and communities from Middle East Asia. The book became a bestseller again in 2011, and French right-winger Marine Le Pen and Steve Bannon, a former Trump adviser, recommended it as favorite literature.

However, whether in the form of an organization or a political party, each of these movements exists not only based on ideas but also based on funds and capital. Their financial flows certainly cannot go unnoticed. I maintain that the right-wing populism we are currently facing is not accidental. It is just a symptom of the need to change democracy. Democracies now operate with 20th-century means and mechanisms. Most populist politicians in democratic regimes aim to distance themselves from the elite and stand by the "right people", and for that reason, the populist label is easily added, regardless of whether they are the intentions of politicians are sincere, or it is populism whose sole purpose is to gather votes.

However, populists do much more than side with the majority; they put populistic rhetoric at the campaign's center. Anti-elitism and collectivism are without that no of their political existence. Their purpose is to create a dominant order and give voice to the collective will of the majority, using goals that bring feeling urging that there is a crisis (Oliver and Rahn, 2016, p. 191). Listed characteristics can be seen in the speeches of two politicians who are in pre-campaigns for the presidential election rated as populist - Donald Trump and Bernie Sanders. While Sanders, on the one hand, had appearances that contained antielitism and provocation elements, this establishment, because of the interests of big business, essentially his campaign was much more than that. Despite the elements of populist rhetoric that were indeed present, the campaign itself is not was based solely on populist elements. Trump is on the other side sides of their communication, fully adapted to the so-called populist moment. The populist moment depends on the consistency of several key factors: appropriate political conditions, a charismatic populist leader, and audience receptivity based on their problems and psychological inclinations.

It is necessary to distinguish between fascist tendencies, the fascist movement, and fascist government. Europe is in danger of the so-called right-wing populism, which is often equated with neo-fascism. The difference between, for example, authoritarian conservatism such as Orban and the Polish ruling party Law and Justice, and openly fascist parties and movements such as e.g., Jobbik and Golden 
Dawn. In many of the examples mentioned, we can see the electoral successes of far-right parties and the flirtation of the political center with these parties and movements, both at the level of rhetoric and within government institutions. We can easily conclude that there are many such tendencies (a combination of ultranationalist narratives and renewal of some aspects of the fascist past), that in some places there are movements (which are often difficult to separate from extraordinarily conservative and nationalist ones), and that there is no fascist government anywhere, which does not mean that in many cases the government uses certain fascist elements to preserve and legitimize itself.

Maintaining international security has recently met with many challenges. The world is facing a global crisis of large migrations, frequent terrorist attacks, constant outbreaks of new wars between nation-states, growing poverty among the population, the outbreak of new diseases, and the like. These are all new causes of uncertainty how national as well as international proportions. From decade to decade, are we forced to renew the spiral of violence, as if we were truly a prehistoric world? I suggest that we take peace for granted, without going into the essence of that phenomenon, both in a theoretical and a practical sense. For example, Scandinavian countries, within completely different paradigms than the one inherited by most of humanity - introduced into educational curricula as early as the 1960s. The transformation of authoritarian regimes into a personal autocratic dictatorship of a populist leader today grows into a recognizable political phenomenon of the modern world. From 1946 to $1999,44 \%$ of authoritarian regimes grew into a personal autocratic dictatorship of the leader (autocracy), while in the period from 2000 to 2010 alone, that percentage rose to a dramatic $75 \%$. It indicates the true face and direction political populism is leading today, which is a cause for great concern and alarm for humanity. The growth of populist parties with authoritarian populist regimes with personal dictatorships of national and religious leaders encourages the tendency to create new regional relations in which a strong and coherent alliance is created between undemocratic and xenophobic regimes that encourage aggressive domestic and foreign policy, which poses a great threat to regional and global peace.

The era of human destruction and the domination of nationalism and political authoritarianism has only just begun and is increasingly leading to the creation of war psychosis and security stalemate. In a global context, not just crimes in New Zealand, but also the one committed by Breivik and in Macerata when L. Traini, sentenced to 12 years, shot at 6 African migrants, there is a common paradigm of reasons for committing such atrocities. In their imaginary imagined struggle for European civilization, Tarrantov, like Brevik's manifesto before him, describes birth rate as a major problem of "indigenous" Europeans who are greatly endangered by migration and the practice of migrants, especially from the East, and a threat to security, identity, and territorial integrity. the existence of "national" indigenous white European communities. Such an idea can be summarized in Karadzic's (Bosnian Serb former politician who served as the president of Respublika Srpska during the Bosnian War, convicted of genocide, crimes against humanity, and war crimes by the International Criminal Tribunal for the former Yugoslavia - ICTY) statement in 2016, after the first-instance verdict, when he actually tried to make a paradigm out of crime with the fight for a "free Europe", and utopianly asked: "Doesn't Europe know when we fought?" alluding to the then terrorist attacks in Paris and Brussels. (Preporod, 2019) Karadzic based his defense on the modern extreme right in Europe about a "clean living space" for indigenous peoples on European soil. In such a constellation of European ideology, Bosnian Muslims were not the actual inhabitants of this area, and the strong presence of the Ottoman Empire in the Balkans further supports the alternative historiography of extreme right-wing movements. Austria has already taken steps to detect such movements and recently opened an investigation against the extreme right-wing Identity Movement led by Martin Sellner, which was also linked to 


\section{Christchurch's alleged terrorist attack.}

The threat to democracy comes precisely from the sphere of the legitimacy of the democratic choice of a populist authoritarian regime (leader), which, based on this "democratic electoral legitimacy", is authorized to make further political and economic changes without any public oversight. The populist regime (leader) derives from that "democratic electoral legitimacy" the legitimate right to abolish any possibility of public criticism that usually qualifies as political resistance of the opposition, or as hostile provocations of the "fifth column" or as a conspiracy of national or religious minorities or migrant groups, which creates a climate of fear, mistrust, and repression, in which new perspectives open up for authoritarian regimes, in whose hands all political power is concentrated. However, Western European societies' history can also be read as a sequence of dominant lines of conflict, starting from the contradictions of Catholicism and Protestantism, the periphery and the center, then the agrarian economy and industry, and so on. When the lines of conflict lose clarity, the old antagonisms do not disappear completely. They still exist and are reflected in party systems.

In the last century, we had the class struggle between capital and labor. In the beginning, the two irreconcilable camps stood facing each other, radicalizing political divisions, bringing political systems sometimes to the point of breaking down and helping the rise of fascism. After the Second World War, this conflict became institutionalized and civilized, at least in the democratic countries of Western Europe and North America. In democratic competition, on the one hand, there were social democratic and socialist parties, which advocated a strong and redistributive state and market restraint. On the other side, there were conservative or liberal parties, which advocated the market, preventing too much state power. However, the left-right scheme that emerged from there will soon dominate all-party systems in Western democracies. The remnants of the old conflict lines are losing their importance, and the conflict between East and West even internalizes this opposition. However, a liberal should be aware of his social responsibility because he is aware that his satisfaction depends on his interaction with other individuals.

\section{Lessons from the Balkans}

Gabriel Almond (1977), hinting at the upcoming political and social processes in Eastern Europe, warned long ago that the main problem would be an inappropriate political culture. It was later confirmed in the results of research conducted by the European Institute of Sussex in countries about to join the EU. Before the war, Yugoslavia, and of course Bosnia and Herzegovina, was equal to Austria and Italy in terms of the standard of living of its population, while Hungary, the Czech Republic, and, of course, the Balkans were not just a laboratory from which doctrinal guidelines of the extreme right in Europe could be drawn.

Initially, the regions politics can be defined as a kind of hybrid regime, such as competitive authoritarianism, characterized by a low level of horizontal accountability, powerful, plebiscitary, and prone to executive power abuses. The main feature of this regime is that formally there are democratic institutions, but very often, there are abuses by the government, which destroys the very essence of democracy (Lewitsky, Way, 2002, p. 53). Democratic institutions are pragmatically-politically viewed as a means of gaining and exercising political authority. Those in power very often and, to such an extent, violate formal rules that the regime does not meet even the usual minimum standards for democracy. The elections, while supposed to be free and fair, are, in fact, a "one-horse race" they deprive the opposition of a chance to win, as the authorities regularly misuse state funds and prevent the opposition from gaining media space. In this context, the election winners acted as if they had received majority support within the pluralistic competition and plebiscitary (Vrcan, 1999) support that legitimized them as complete masters of political communities. According to Guillermo O'Donnell (1994), a form of regime close to competitive authoritarianism is "delegate democracy". Over half of all the new electoral democracies represent specific 
variants of diminished sub-types of democracy, which can be called defective democracies starting from the root concept of embedded democracies, which consists of five interdependent partial regimes (electoral regime, political rights, civil rights, horizontal accountability, sufficient power to govern). In such states, there are signs of competition between stabilizing and modernizing movements, collectively referred to as "development" or "progressive power", and destructive, criminalizing tendencies.

It is often forgotten that both types of tendencies have internal, essential interests that guide them towards cooperation. The least controversial and simplest point of contact between these seemingly opposing social tendencies is focused on the possibility of concretely achieving the goals they have made public as their commitments. For example, progressive political forces must prove that they are achieving certain goals: they are "delivering results", both because of their international partners and local support. In that endeavor, they face many obstacles. Namely, they encounter social and even state structures, in which the factual knowledge and means for achieving the results that they proclaimed as their lie in the hands of people who are not members of these progressive forces themselves. For example, in the police and state security services, the expertise and resources for its use are often in the hands of people who are not in the same political "basket" as the democratizing and "progressive" forces in society.

The situation is similar in other areas where there are legitimate social goals. Unlike left and right populism, where the means are the same, regardless of the differences in goals, when it comes to the attitude towards an open society, the goals of left and right populists are more similar than the means. There are differences between left and right populism in its conceptualization in how it is reached. One of the similarities is that both left and right populists see alienated elites, who are either non-national or selfish, those responsible for negative cultural or social movements. It is for both national or social; homogeneity is the goal that politics should strive for, although how it should be achieved is different, except that they are in some general sense protectionist because they should protect the nation or society from external influences one kind or another. Serbia's example shows quite clearly how the political paralysis and ideological radicalization of nationalism, along with war goals, leads to populist and authoritarian rule. Her fate, as in other cases, was tied to the outcome of the war. While political and territorial goals remained unfulfilled by defeats in wars, the prevailing nationalist ideology survived and remained predominant in the public eye. As well as the associated tendency towards authoritarianism. The growth of populist options also took place in Croatia, so after the emergence of various "alternatives" that were neither alternatives nor knew how to use populism to their advantage in the long run, such as Laborists, the party "Zivi zid" emerged on the political scene. There is a constant interethnic escalation of tensions in Croatia, mainly in the period ahead of the ICTY's "Six" (The ICTY issued an indictment for six former Bosnian HRHB leaders - J. Prlić, B. Stojić, S. Praljak, M. Petković, V. Ćorić and B. Pušić. The ICTY sentenced all six.) verdict in 2017. "Persistent denial of the International Criminal Tribunal for Former Yugoslavia convictions of high-ranking participants by Croatian politicians and manipulating the public is entirely at the joint criminal" (Hadžić, 2020, p. 124) and fascist enterprise level. The Yugoslav conflicts, supported by neo-Nazism, mythology, ethnic chauvinism, religious extremism, as a mobilizing ideology, have created an explosive, dangerous and traumatic environment in which the possibility of a multiethnic-religious dialogue in this area is increasingly being challenged. In the absence of global democratic order, the fluid, fragmented, and old-fashioned fight against racial, interfaith and intercultural hatred and animosity remain, which is a time of the digitaltechnological revolution. "Growing authoritarian populism creates new multiple threats that could explode into a further escalation of conflict in the Balkans and could 
have dramatic consequences for all of humanity" (Hadžić, 2020, p. 2).

Why would the dark side of Balkan history and its negative characters from the past and present be of interest to extremist radical groups and individuals who speak of the vulnerability of the white race, the Christian world, or one nation in general? The absence of a law banning neo-fascist organizations and movements in Bosnia and Herzegovina allows for the legal promotion of hatred and criminals, as well as ideas that lead society to degradation. For Europe and the world, this can signal how, by legal omissions, extreme right-wing organizations are recruited in the countries in which they exist and what kind of content they share through social networks. Real information about their activities online, from which terrorists like Brentton Tarrant, and potentially others, learn, allows taking proactive action against terrorist intentions, not just action. The final verdict against a criminal like Karadzic is not a verdict for the people to which he belongs, but it is a verdict for a plan for a genocidal policy of cleansing a people from the Balkans. The verdict will certainly not change the awareness of many in this area about the magnitude of the crime committed and the consequences it produced. It was confirmed by the recent regular gatherings of the Chetnik movement (members of the Serbian nationalist-chauvinist movement of Greater Serbia ideology) in Ravna Gora and the lack of an adequate rule of law in the case of the protection of returnees in the Bosnia and Herzegovina entity of RS. After all, the government of this entity, immediately the day after the verdict, awarded $30,000 \mathrm{~km}$ in grant funds for the organization led by another Hague convict, Momcilo Krajisnik. Media coverage was reduced to a verdict "that will not bring reconciliation" in this area. According to the media, the question is what other verdicts could pass if there is no awareness of guilt for the crime. Moreover, at the tribune in Podgorica, Montenegro, on the "creation of RS", in which Krajisnik participated, Karadzic from the detention unit made a phone call, which passed without the sanctions of the International Residual Mechanism for Criminal Courts (Preporod, 2019).

Historiographically, going through the Balkans writing the names of those who committed crimes against one nation on its soil is not a naive and only passionate endeavor of the Australians Tarrant and his musical distaste for the Balkan war-propaganda turbo-folk. Orban's office is not decorated with an ethnic map of Bosnia and Herzegovina for no reason, nor is his posing with D. Murray's book "Strange death of Europe: immigration, identity, Islam" (2007) on the destruction of Europe by migrants. In the end, Anders Breivik also, by chance, did not find the inspiration to cleanse Europe of Muslims in the work of life-sentenced war criminal R. Karadzic.

Why would the dark side of Balkan history and its negative characters from the past and present be of interest to extremist radical groups and individuals who speak of the endangerment of the white race, the Christian world, or one nation at all? Due to the general disappointment with the political process, political duopoly, and lack of true political pluralism in Croatia as a full Western Balkan member of the European Union, several parallel processes have emerged that will cause longterm disintegration of society and the state. The most obvious example is the demographic catastrophe that directly leads to society's collapse because the productive part of the population, mostly of younger age, is leaving the country, which is the carrier of economic and biological reproduction. Today, the economic situation has only partially improved, thanks to EU funds, in Croatia. However, in the long run, the system has caused the largest exodus of the population, reducing the tax base and jeopardizing pension health systems. A recent survey (2018) in Croatia shows that the main reasons for mass emigration are "an unorganized and corrupt state" (Juric, 2018). For those who still want to fight for a better tomorrow but have not left, only the bottom-up approach remains. 


\section{Conclusions}

Populism implies a constant conflict between elite, establishment, alienated structures linked to interests contrary to the public or members of other ethnoreligious backgrounds. Moreover, it is populism the more pronounced, the stronger the intensity of this conflict. Populism is becoming more and more a substitute for various types of fascism, and with that replacement, it can become politically correct. Populism is a kind of reaction to the democracy crisis. The focus of power is not marked, social inequality is growing, and social cohesion decreases. Both left and right populism aim at a particular political and social homogeneity.

Probably one of the best lessons comes from the Balkans in dealing with similar individuals and movements that promote the "cleansing" of Europe, and the preservation of an "identity" artificially tailored to the hatred of others is proactivity.

The Balkans' historical experience and its (un) successful fight against the old forms of rightwing extremism in more current circumstances have become like an overflowing foundation in right-wing networks throughout Europe and the world.

While right-wingers like Tarrant or Breivik and their like-minded people learn from this region's criminal names for their goals, a healthy civilized part of Europe and the world needs to learn what follows if crime and terror are forgotten, concealed, and not sanctioned. Humankind's great concern stems from the increasingly aggressive foreign policy, xenophobic sentiment, and the growing inclination of the autocratic populist government to stop the transition of violence to democracy in the scientifically-technologically and culturally-spiritually objectively connected global community. More and more conditions their connection with the most problematic (dictatorial) regimes in the world.

The threat to global democracy comes precisely from the sphere of the legitimacy of the democratic choice of a populist authoritarian regime (leader), which, based on this "democratic electoral legitimacy", is authorized to make further political and economic changes without public oversight. Hence the phenomenon of increased countries with developed democratic institutions and standards with authoritarianism leads to a closed circle of global "legitimate-democratic" violence, in which democratic institutions and standards, human and minority rights, and freedoms will be a danger. To avoid complete social disintegration, we cannot continue current practices or go into populism. Solutions based on opportunism and manipulation do not offer anything concrete that could improve the socio-political-security-economic situation in the long run.

Precisely, when a liberal sees that certain elements use coercion to regulate social relations according to their desire, to force the whole of society on acceptable socio-economic behavior, the liberal should feel a personal responsibility to stand up for freedom. Furthermore, to defend freedom, one needs to have allies, one needs to act with other individuals voluntarily, one needs to gather freethinking individuals and fight for social and thus personal freedom because it is in his best interest.

Manipulation of the people will cease to be useful when the force at the disposal of populism breaks. When and how this will happen is a great dilemma of this age, which remains outside this consideration's scope.

\section{References}

Almond, G., (1977) Political Development in Eastern Europe, Praeger Publishers New York London

Arditi, B. (2005) Populism as an internal periphery of democratic politics. In Populism and the Mirror of Democracy, ed. Francisco Panizza. Verso Books, London

Crouch, C. (2007) Postdemokracija, Političke i poslovne elite u 21. stoljeću, Izvori, BS-05421 Case no. IT-04-74-T, ICTY, Second amended 
indictment: Prosecutor of the tribunal. In 2004, the ICTY issued an indictment for six former HRHB leaders - J. Prlić, B. Stojić, S. Praljak, M. Petković, V. Ćorić and B. Pušić.

Hadžić, F. (2020) The influence of social media on threats to identity, stability and national security; institutional inefficiency and vulnerability of B\&H, Defendology 2020, No. 45-46, DOI: 10.7251/DEFEN4520067H, European Defendology Center

Hadžić, F. (2020) The European Union (EU) Political Identity within the migrant crisis, and the Balkan - Bosnian route; xenophobia and religious identity. Research, Society and Development, 9(10). DOI: 10.33448/rsdv9i10.8685

Hadžić, F., Hadžić,F. (2020) Post-Yugoslav spaces between defective democracies, authoritarianism, and kleptocracies, International Affairs and Global Strategy, Vol. 86, P. 38-52. DOI: 10.7176/IAGS/86-04

Jurić, T. (2018) Emigration of Croats to Germany. Are we losing Croatia? Školska knjiga, Zagreb

Konstantinovic, R. (2009) Filozofija palanke, ISBN 978-9958-635-54-0, University press

Levitsky, S., Way, L. (2002) The rise of competitive authoritarianism, avalible at https://scholar.harvard.edu/levitsky/files/SL _elections.pdf

Mudde, C., and Kaltwasser, C. (2013) Exclusionary vs. Inclusionary Populism: Comparing Contemporary Europe and Latin America, Government and Opposition, Volume 48 Issue 2. avalible at DOI: 10.1017/gov.2012.11

Oliver, J. and Rahn, W. (2016) Rise of the Trumpenvolk: Populism in the 2016, Election, The Annals of the American Academy, AAPSS

Papić,̌̌. (2002) Bosnia and the Balkans, possibilities, and conditions for recovery, Forum Bosna, Sarajevo,No. 17/02

Polanji, K, (2003), Velika transformacija,Politička i ekonomska ishodišta našeg vremena, Filip Višnjić

Preporod, (2019) "Šta iskustvo Balkana može naučiti Evropu i svijet", Avalible at https://www.preporod.info/bs/article/5158/ sta-iskustvo-balkana-moze-nauciti-evropu-isvijet

Timbro, Report, (2017). Avalible at https://timbro.se/allmant/timbroauthoritarian-populism-index2017/

Salaj, B. And Grbesa, M. (2018) Dobar, loš ili zao? Populizam u Hrvatskoj, TIM Press,Zagreb

Vrcan, S. (1999) Packaging of power: elections in Croatia in 1995 and 1997, Zagreb, Alinea 